\title{
KENAKALAN REMAJA DAN KEDISIPLINAN: Perspektif Psikologi dan Islam
}

\author{
Nikmah Rahmawati \\ Universitas Islam Negeri (UIN) Walisongo Semarang \\ e-mail: nikmahrahmawati@yahoo.com
}

\begin{abstract}
Abstrak
Kedisiplinan dan kenakalan remaja itu memang ada keterkaitan yang erat. Banyak yang membuktikan hal itu melalui berbagai penelitian yang telah disebutkan dalam pembahasan di atas. Dalam hal ini, kedisiplinan itu berkorelasi terbalik dengan kenakalan remaja. Artinya, jika seorang remaja itu disiplin dan menerapkan kedisiplinan tersebut di dalam berbagai aspek kehidupannya, maka remaja tersebut akan berkurang tingkat kenakalannya yang bersifat destruktif, bahkan akan tereliminasi sama sekali. Karena itulah, faktor terpenting dalam menghentikan kenakalan remaja adalah bagaimana menerapkan kedisiplinan pada diri remaja di dalam berbagai aspek kehidupannya.
\end{abstract}

Kata Kunci: kenakalan remaja; kedisiplinan; psikologi;

Islam

\section{A. Pendahuluan}

Perilaku remaja pada saat ini begitu sangat mengkhawatirkan. Ada banyak perilaku yang bersifat destruktif, seperti tawuran, geng-gengan, minuman keras, perilaku seks bebas, pencurian, pemerkosaan, perampokan, dan banyak lagi. Hal ini tentu saja memunculkan keprihatinan tersendiri dan sekaligus menjadi tamparan keras bagi praktik pendidikan di Indonesia. Perilaku remaja tersebut menjadi ukuran apakah praktik pendidikan di Indonesia sudah berhasil ataukah tidak.

Kenakalan remaja (juvenile delinquency) adalah perilaku yang mencerminkan adanya kesalahan dalam pola pendidikan, baik itu pendidikan di rumah dan masyarakat maupun di sekolah. Tentu saja hal ini tidak bisa dinilai dari satu aspek, tapi harus melibatkan banyak aspek, termasuk aspek individu remaja itu sendiri. Pada dasarnya, terjadinya kenakalan remaja menunjukkan adanya ketidakdisiplinan remaja terhadap aturan dan norma yang berlaku, baik itu keluarga, sekolah, masyarakat maupun norma diri 
sebagai individu, dan penanaman norma tersebut sebelumnya tentu harus diberikan kepada individu remaja agar mereka mempunyai pemahaman yang baik terkait dengan norma tersebut.

Penyebab kenakalan tersebut di antaranya adalah akibat pola asuh orang tua yang salah, lingkungan sekolah yang tidak baik, peer group yang buruk, lingkungan sosial dan masyarakat yang tidak kondusif, kontrol diri yang lemah, dan kematangan emosi remaja yang tidak berkembang sesuai dengan tingkat usia perkembangan remaja. Karena itulah tulisan ini berusaha mengupas penyebab kenakalan remaja dan langkah preventifnya serta bagaimana cara meningkatkan kedisiplinan remaja dalam perspektif psikologi dan Islam.

\section{B. Kenakalan Remaja dan Kedisiplinan dalam Perspektif Psikologi Barat}

\section{Kedisiplinan dan Kenakalan Remaja}

Hurlock menjelaskan bahwa disiplin adalah cara mendidik individu untuk mengembangkan kontrol diri dan arah diri serta mampu menyesuaikan diri dengan harapan yang diterima di lingkungan sosialnya sehingga individu dapat bertindak dan mengambil keputusan dengan bijaksana. ${ }^{1}$ Santrock mendefinisikan Kenakalan remaja (juvenile delinquency) sebagai perilaku yang tidak dapat diterima secara sosial seperti bertindak berlebihan di sekolah, pelanggaran, mencuri, melarikan diri dari rumah dan tindakan kriminal lainnya. ${ }^{2}$

Kenakalan remaja memiliki korelasi dengan kedisiplinan. Kenakalan remaja atau perilaku menyimpang disebabkan karena ketidakdisiplinan remaja terhadap aturan yang berlaku di dalam keluarga, masyarakat atau sekolah. Penyebab ketidakdisiplinan remaja terhadap aturan yang berlaku adalah karena kurangnya kontrol diri dan gagalnya penyesuaian terhadap lingkungan (maladjustment), di samping juga karena kurangnya kontrol diri yang disebabkan kematangan emosi yang masih labil.

Selain faktor dari dalam diri remaja, kenakalan remaja juga disebabkan oleh faktor dari luar diri, yaitu lingkungan yang tidak baik seperti pola asuh

\footnotetext{
${ }^{1}$ Elizabeth Hurlock, Perkembangan Anak, Jilid 1 dan 2. Alih bahasa Tjandrasari, M. \& Muslichah, (Jakarta: Erlangga, 1993).

${ }_{2}^{2} J o h n$. W. Santrock, Perkembangan Masa Hidup Jilid 1 dan 2. (Jakarta : Erlangga, 2012).
} 
salah dari orang tua, lingkungan sekolah yang tidak baik, peer group yang buruk, lingkungan sosial dan masyarakat yang tidak kondusif.

Nindya, dkk. menemukan bahwa kekerasan emosional yang terjadi pada anak yang menjadi korban kekerasan emosional berkorelasi dengan kecenderungan kenakalan remaja. Kematangan diri secara emosional (maturing emotional self) menunjuk pada emosi yang menyangkut semua wilayah perilaku afektif dengan melibatkan aspek biologis, kognitif, dan sosial. ${ }^{3}$ Lugo Gorlow menyatakan bahwa kematangan emosi merupakan proses dimana pribadi individu secara terus-menerus berusaha mencapai suatu tingkatan emosi yang sehat, baik secara intrafisik maupun interpersonal. Individu yang secara emosional telah matang dapat menentukan dengan tepat kapan dan sejauh mana dirinya perlu terlibat dalam suatu masalah sosial serta dapat memberikan jalan keluar atau pemecahan yang diperlukan. ${ }^{4}$

Aroma menjelaskan bahwa terdapat hubungan negatif antara tingkat kontrol diri dengan kecenderungan perilaku kenakalan remaja. Semakin tinggi tingkat kontrol diri, semakin rendah kecenderungan perilaku kenakalan remaja. Sebaliknya, semakin rendah tingkat kontrol diri, semakin tinggi perilaku kenakalan remajanya. ${ }^{5}$ Dengan nada yang sama, Kusumadewi menyatakan bahwa terdapat hubungan positif antara dukungan sosial peer group dan kontrol diri dengan kepatuhan terhadap peraturan. ${ }^{6}$ Selain itu, Pravitasari menemukan bahwa ada hubungan antara persepsi pola asuh permisif dengan perilaku membolos.7 Begitu juga dengan Evi yang menjelaskan bahwa ada hubungan negatif yang sangat signifikan antara kontrol

\footnotetext{
${ }^{3}$ Nindva, P. N., and R. Margaretha. "Hubungan antara Kekerasan Emosional pada Anak terhadap Kecenderungan Kenakalan Remaja." Jurnal Psikologi Klinis dan Kesehatan Mental 1.03 (2012).

${ }^{4}$ Muawanah. Lis Binti. "Kematangan emosi, konsep diri dan kenakalan remaja."Jurnal PERSONA1.1 (2012).

${ }^{5}$ Aroma, Iga Serpianing, and Dewi Retno Suminar. "Hubungan Antara Tingkat Kontrol Diri Dengan Kecenderungan Perilaku Kenakalan Remaja." Jurnal Psikologi Pendidikan dan Perkembangan Vol 01 No 2 (2012).

${ }^{6}$ Kusumadewi, Septi, Tuti Hardiaiani, and Aditva Nanda Privatama. "Hubungan antara dukungan sosial peer group dan kontrol diri dengan kepatuhan terhadap peraturan pada remaia putri di Pondok Pesantren Modern Islam Assalam Sukoharjo." Jurnal Ilmiah Psikologi Candrajiza 1.2 (2012).

${ }^{7}$ Pravitasari, Titis. "Pengaruh Persebsi Pola Asuh Permisif Orang tua terhadap Perilaku Membolos." Educational Psychology Journal 1.1 (2012).
} 
diri dengan kenakalan remaja. ${ }^{8}$ Sedangkan Alboukordi menyatakan bahwa keutuhan keluarga, kontrol orang tua dan afiliasi dengan teman sebaya yang nakal berkorelasi positif terhadap terjadinya kenakalan remaja. ${ }^{9}$

Dalam penelitian lainnya, Siswanto menemukan bahwa ada hubungan negatif yang sangat signifikan antara kedisiplinan melaksanakan shalat wajib dengan prokrastinasi akademik. Artinya, semakin tinggi kedisiplinan melaksanakan shalat wajib, akan diikuti semakin rendahnya prokrastinasi akademik. Sebaliknya, semakin rendah kedisiplinan melaksanakan shalat wajib, akan diikuti semakin tingginya prokrastinasi akademik. Prokrastinasi akademik adalah perilaku menunda-nunda dalam mengerjakan atau menyelesaikan tugas akademik. Seseorang yang mempunyai kecenderungan untuk menunda, atau tidak segera memulai suatu kerja, ketika menghadapi suatu kerja ataupun ketika menghadapi suatu tugas disebut sebagai seorang yang melakukan prokrastinasi. Seseorang yang melakukan penundaan tugas akademiknya, pada saat mengerjakan tugas tersebut hingga mendekati batas waktu yang ditentukan, akan cenderung mengerjakannya dengan ceroboh dan terburu-buru. Perilaku menunda menyebabkan beberapa masalah yang muncul pada diri yang bersangkutan, yakni rusaknya motivasi mental dan disiplin sehingga banyak sekali waktu terbuang sia-sia dan kinerja akademik buruk, motivasi belajar rendah, kognisinya irasional, obsesif dan kompulsif, rendahnya harga diri, kepercayaan diri, atau bahkan sampai ke tahap kecemasan yang tinggi..$^{10}$

\section{Mengurangi Kenakalan Remaja dan Meningkatkan Kedisiplinan}

Mendidik karakter adalah menanamkan nilai-nilai kepada siswa. Nilainilai yang ditanamkan adalah nilai-nilai yang terdapat dalam agama, Pancasila, budaya, dan nilai-nilai yang tersurat dalam tujuan pendidikan

${ }^{8}$ Evi Avivah and Muhammad Farid. "Religiusitas, Kontrol Diri dan Kenakalan Remaja." Persona 3.02 (2014).

9Saiad Alboukordi, et al. "Predictive Factors for Juvenile Delinquencv: the Role of Familv Structure, Parental Monitoring and Delinquent Peers." International Journal of Criminology and Sociological Theory 5.1 (2012).

${ }^{10}$ Siswanto, Fevi Zanfiana. "Hubungan Antara Kedisiplinan Melaksanakan Sholat Wajib dengan Prokrastinasi Akademik pada Mahasiswa di Fakultas Farmasi Universitas Ahmad Dahlan." Empathy: Jurnal Fakultas Psikologi 2.1 (2013). 
nasional,yang diperinci menjadi nilai-nilai seperti nilai religius, kejujuran, toleransi, kedisiplinan, kerja keras, kreativitas, kemandirian, demokratis, rasa ingin tahu, semangat kebangsaan, cinta tanah air, menghargai prestasi, bersahabat/komunikatif, cinta damai, gemar membaca, peduli lingkungan, peduli sosial, dan tanggung jawab yang dikristalkan menjadi cerdas, tangguh, jujur, dan peduli.

Nilai disiplin berkorelasi dengan kenakalan remaja. Disiplin bukan hanya tepat waktu saja, tetapi juga patuh pada peraturan-peraturan yang ada, yaitu melaksanakan yang diperintahkan dan meninggalkan segala yang dilarang. Di samping itu, perbuatan tersebut harus dilakukan secara teratur dan terus-menerus walaupun hanya sedikit.

Remaja yang nakal adalah remaja yang tidak disiplin. Penanaman nilai-nilai untuk meningkatkan karakter disiplin dalam rangka mengurangi kenakalan remaja harus menyesuaikan tahap perkembangan penalaran moral siswa, yaitu kemampuan menilai mana yang baik dan mana yang buruk. Pada siswa SD, kontrol eksternal (guru, orangtua) mutlak diperlukan. Dalam hal ini, pendekatan behavioristik lebih efektif. Jika lingkungan anak baik, anak akan baik, dan begitu juga sebaliknya.

Proses pembelajaran karakter, menurut pendekatan behavioristik, dilakukan dengan cara modelling. Artinya, penalaran moral anak usia akhir SD sampai awal SMP akan ditentukan oleh perilaku yang sesuai dengan harapan atau tuntutan dari orang-orang pemegang otoritas dan kelompok sebaya. Pada tahapan ini, posisi pendidik sangat strategis untuk mengembangkan karakter siswa melalui peneladanan. Orangtua dan guru sebagai figur pemegang otoritas haruslah bersikap bijaksana dan berperilaku yang dapat dijadikan suri teladan bagi perilaku anak.

Sedangkan penalaran moral siswa level SMA akan berbeda lagi, karena mereka sudah memiliki kesadaran penuh tentang penting dan kegunaan menaati aturan-aturan moral dan hukum. Sedangkan, penalaran moral pada mahasiswa, akan semakin meningkat kesadaran penilaiannya, dan mereka dianggap sudah mampu menilai bahwa hukum harus terbuka untuk dievaluasi. Hukum adalah bagus kalau ia melindungi hak setiap individu. ${ }^{11}$

\footnotetext{
${ }^{11}$ Robert E. Slavin, Psikologi Pendidikan: Teori dan Praktik, edisi kesembilan, jilid 2, (Jakarta: PT Indeks, 2011).
} 
Lawrence Kohlberg membagi perkembangan moral manusia menjadi 3 tingkat, yaitu: pertama, tahap pra konvensional di mana pertimbangan moral semata-mata berdasarkan kebutuhan dan persepsi orang tersebut. Kedua, tahap konvensional, yaitu penalaran moral berdasarkan ekspektasi masyarakat dan hukum yang berlaku di masyarakat. Ketiga, tahap pasca konvensional, yaitu penalaran moral yang didasarkan pada prinsip-prinsip yang lebih pribadi dan abstrak tentang keadilan yang belum tentu sama dengan yang didefinisikan oleh hukum masyarakat. ${ }^{12}$

Kenakalan remaja dapat diminimalisasi dan ditanggulangi dengan meningkatkan dan memperkuat karakter kedisiplinan. Cara meningkatkan dan memperkuat karakter kedisiplinan adalah: Pertama, mendidik dan mengenalkan nilai-nilai kedisiplinan dan bahaya kenakalan remaja secara kognitif dan juga melalui penghayatan secara afektif, serta mengamalkan nilai-nilai tersebut secara nyata.

Kedua, guru atau orang tua menjadi teladan yang baik bagi anak. Dalam hal ini, teori social learning Albert Bandura menyebutkan bahwa belajar itu terjadi melalui observation learning dan vicarious learning. Observation learning adalah siswa atau anak meniru perilaku guru atau orang tuanya dalam banyak nilai: kedisiplinan, kejujuran, komitmen, tanggung jawab, religiusitas, kerja keras, kedemokratisan, dan sebagainya. Sedangkan vicarious learning adalah meniru perilaku siswa lain yang memperoleh reinforcements. ${ }^{13}$ Ada prinsip lain yang mengantarai keduanya, yaitu prinsip triadic reciprocal interaction, yaitu suatu perilaku itu dipengaruhi secara timbal balik oleh diri dan lingkungan. Guru yang bersikap tidak baik kepada siswa akan disikapi secara tidak baik pula oleh siswa. ${ }^{14}$

Albert Bandura yakin bahwa perkembangan moral dapat dipahami dengan baik jika mempertimbangkan kombinasi faktor sosial dan kognitif, terutama yang melibatkan kontrol diri. Teori belajar sosial dari Bandura memberikan penekanan pada tingkah laku moral remaja. Proses reinforcement (penguatan), hukuman dan imitasi digunakan untuk menjelaskan 2009).

${ }^{12}$ Anita Woolfolk, Educational Psychology, Jilid 1 and 2. (Yogyakarta: Pustaka Pelajar, 2014).

13John. W. Santrock, Psikologi Pendidikan, Jilid 1 dan 2. Jakarta: Salemba Humanika,

${ }^{14}$ Jeanne Ellis Ormrod, Psikologi Pendidikan, Jilid 1 dan 2, (Jakarta: Erlangga, 2009). 
bagaimana dan mengapa remaja mempelajari beberapa tingkah laku moral tertentu. Ketika remaja mendapatkan penguatan untuk melakukan suatu tingkah laku yang sesuai dengan hukum dan konvensi sosial, mereka cenderung mengulangi tingkah laku tersebut. Begitu juga ketika mereka dihadapkan pada model yang bertingkah laku "secara moral", para remaja juga cenderung meniru tingkah laku model tersebut. Ketika remaja dihukum karena tingkah laku yang tidak bermoral atau tidak dapat diterima, tingkah laku ini juga dapat dihilangkan. Tetapi memberikan sanksi berupa hukuman yang dapat mengakibatkan efek samping emosional pada remja. ${ }^{15}$

Ketiga, menggunakan metode pembelajaran pada ranah afektif yang sesuai dengan values (nilai-nilai). Pembelajaran untuk menanamkan values harus menyentuh level ketiga dari ranah afektif, yaitu valuing; yang selanjutnya diikuti dengan organizing values, dan internalizing values. Valuing adalah kemampuan memberikan penilaian terhadap sesuatu yang kemudian memunculkan sikap menerima, menolak, atau mengabaikan sesuatu. Organizing values into priorities adalah kemampuan membentuk suatu sistem nilai yang diprioritaskan sebagai pedoman dalam kehidupan. ${ }^{16}$

Internalizing values adalah kemampuan menghayati dan menginternalisasi nilai-nilai kehidupan menjadi milik pribadi dan menjadi pegangan dalam kehidupan. Untuk menginternalisasi nilai-nilai yang akan menjadi pedoman dalam kehidupan membutuhkan minat tinggi (keinginan kuat). Untuk mengembangkan nilai-nilai tersebut dituntut pembelajaran yang mengharuskan siswa aktif mengalami (strategi experiential learning). Strategi experiential learning meliputi metode simulasi, field trip, eksperimen, focused imaging, games, observasi lapangan, dan role playing.

Keempat, mengembangkan atribusi usaha (kerja keras, tanggung jawab), menghargai semua usaha kreatif atau ekspresi positif siswa dalam konteks akademik (kreativitas, menghargai prestasi), menghindari labeling negatif (usaha, harga diri), mengembangkan penilaian berdasar kinerja dan portofolio (kemandirian, kedisiplinan, tanggung jawab), menggunakan pendekatan humanistik dalam berinteraksi dengan siswa (konsep diri, kreativitas), mengembangkan dan memfasilitasi potensi menonjol siswa

${ }^{15}$ John. W. Santrock, Adolescence. (Jakarta : Erlangga, 2003).
${ }^{16}$ Anita Woolfolk, Educational Psychology. 
(inisiatif, kreativitas), menekankan kepada siswa bahwa belajar adalah proses, bukan semata-mata mengejar hasil (kedisiplinan, kejujuran, kerja keras, tanggung jawab), menyediakan kesempatan untuk meraih sukses bagi semua siswa (kerja keras, kepribadian), melibatkan siswa dalam membuat peraturan sekolah/kelas, dan terapkan secara konsisten (demokratis, tanggung jawab, toleransi, peduli lingkungan). ${ }^{17}$

\section{Meningkatkan Kedisiplinan dan Mengurangi Kenakalan Remaja dalam Perspektif Islam}

Islam mengajarkan umatnya agar benar-benar memperhatikan dan mengaplikasikan nilai-nilai kedisplinan dalam kehidupan sehari-hari untuk membangun kualitas kehidupan masyarakat yang lebih baik. Seperti perintah untuk memerhatikan dan menggunakan waktu sebaik-baiknya. Dalam Al-Qur'an disebutkan beberapa kata yang menyangkut kedisiplinan dan waktu, di antaranya adalah: wal-fajri (demi waktu Subuh), wadh-dhuhâ (demi waktu pagi), wan-nahar (demi waktu siang), wal-ashr (demi waktu sore), atau wal-lail (demi waktu malam).

Ketika Al-Qur'an mengingatkan demi waktu sore, kata yang dipakai adalah "al-'ashr"yang memiliki kesamaan dengan kata "al-'ashîr"yang artinya "perasan sari buah". Seolah-olah Allah mengingatkan segala potensi yang kita miliki sudahkah diperas untuk kebaikan? Ataukah potensi itu kita sia-siakan dari pagi hingga sore? Jika demikian, pasti kita akan merugi. "Demi masa, sesungghnya manusia itu benar benar dalam kerugian"(QS. al'Ashr [103]: 2).

Dari ayat tersebut dapat disimpulkan bahwa Al-Qur'an mengajarkan umatnya untuk pandai-pandai menggunakan waktu dengan sebaik-baiknya dengan mempertimbangkan kebahagiaan dunia dan akhirat. Umat Islam tidak diperbolehkan hanya menggunakan waktu untuk kepentingan akhirat saja dengan mengorbankan kepentingan duniawi, atau sebaliknya. Menggunakan waktu dalam usaha mencari karunia dan ridha Allah hendaknya seimbang dan proporsional untuk kehidupan dunia dan akhirat.

Selain itu, Al-Qur'an juga memerintahkan untuk menekuni bidang tertentu hingga menghasilkan karya atau keahlian tertentu sesuai potensi

\footnotetext{
${ }^{17}$ John. W. Santrock, Psikologi Pendidikan.
} 
yang dimiliki. Masing-masing orang dengan keahliannya diharap dapat saling bekerja sama dan bahu-membahu menghasilkan buah karya yang bermanfaat bagi banyak orang.

"Tiap-tiap orang berbuat menurut keadaannya masing-masing. Maka Tuhanmu lebih mengetahui siapa yang lebih benar jalannya." (QS. Al-Isrâ’ [17]: 84)

Pesan moral yang terkandung dalam ajaran Islam, seperti yang termaktub dalam ayat Al-Qur'an di atas, memberi interpretasi yang lebih luas dan jelas kepada umatnya untuk berlaku dan bertindak disiplin. Bahkan dari beberapa rangkaian ibadah, seperti shalat, puasa, zakat maupun haji, terkandung perintah untuk berlaku disiplin. Dengan demikian, nilai-nilai moral yang terkandung dalam ajaran Islam diharapkan mampu menjadi energi pendorong pelaksanaan kedisplinan. Dalam skala lebih luas, untuk meningkatkan kualitas kehidupan masyarakat.

Islam juga memerintahkan umatnya untuk selalu konsisten terhadap peraturan Allah yang telah ditetapkan. Hal ini sesuai dengan firman Allah dalam surat Hud [11] ayat 112:

"Maka tetaplah kamu pada jalan yang benar, sebagaimana diperintahkan kepadamu dan (juga) orang yang telah taubat beserta kamu dan janganlah kamu melampaui batas. Sesungguhnya Dia Maha Melihat apa yang kamu kerjakan".

Dari ayat di atas, disiplin bukan hanya tepat waktu saja, tetapi juga patuh pada peraturan-peraturan yang ada, yaitu melaksanakan apa yang diperintahkan dan meninggalkan segala yang dilarang. Di samping itu juga melakukan perbuatan tersebut secara teratur dan terus-menerus walaupun hanya sedikit. Karena selain bermanfaat bagi diri sendiri, kontinuitas suatu perbuatan juga sangat dicintai Allah walaupun hanya sedikit.

Disiplin pribadi merupakan sifat dan sikap terpuji yang menyertai kesabaran, ketekunan dan lain-lain. Orang yang tidak mempunyai sikap disiplin pribadi sangat sulit mencapai tujuan. Setiap pribadi mempunyai kewajiban untuk membina disiplin diri melalui latihan, misalnya di rumah atau di masyarakat. Dengan demikian, anak selain sebagai seorang siswa yang harus memiliki disiplin belajar di sekolah, juga harus memiliki disiplin belajar di rumah maupun di lingkungan masyarakat di mana anak tersebut tinggal seperti belajar di masjid, mushala, sanggar, atau yang lainnya. Jadi, 
sikap disiplin pribadi seorang anak di dalam belajar akan tecermin dalam kedisiplinan menggunakan waktu, baik waktu dalam belajar ataupun waktu dalam mengerjakan tugas, serta menaati tata tertib atau yang lainnya.

Jadi, seseorang hendaknya memiliki self-discipline dalam kehidupannya, dan sebagai orang Islam hal ini akan berhasil didapatkan dengan cara memindahkan nilai-nilai moral yang terkandung dalam rukun iman. Iman berfungsi bukan hanya sebagai pengarah tingkah laku bila berhadapan dengan nilai-nilai positif yang membawa kepada nilai keharmonisan dan kebahagiaan masyarakat. Iman juga berfungsi sebagai pencegah dan pengawas bila berhadapan dengan nilai-nilai yang menyimpang, sehingga segala perbuatan seolah-olah ada yang mengawasi. Jadi, kita akan dapat bertindak secara hati-hati.

Karena itulah, hal yang paling krusial dari disiplin adalah kepatuhan untuk menghormati dan melaksanakan suatu sistem yang mengharuskan orang untuk tunduk kepada keputusan, perintah dan peraturan yang berlaku. Dengan kata lain, disiplin ini merupakan sikap menaati peraturan dan ketentuan yang telah ditetapkan tanpa pamrih.

Dalam ajaran Islam, banyak ayat al-Qur'an dan Hadis yang memerintahkan disiplin dalam arti ketaatan pada peraturan yang telah ditetapkan. Dalam QS. al-Nisa ayat 59 disebutkan:

"Hai orang-orang yang beriman, taatlah kamu kepada Allah dan taatlah kepada Rasul-Nya dan kepada ulil amri dari (kalangan) kamu ..." (QS. An-Nisa [34]: 59)

Dalam Islam, disiplin adalah kunci sukses, sebab dalam disiplin akan tumbuh sifat yang teguh dalam memegang prinsip, tekun dalam usaha maupun belajar, pantang mundur dalam kebenaran, dan rela berkorban untuk kepentingan agama dan jauh dari sifat putus asa. Perlu kita sadari bahwa betapa pentingnya disiplin dan betapa besar pengaruh kedisiplinan dalam kehidupan, baik dalam kehidupan pribadi, bermasyarakat, berbangsa maupun kehidupan bernegara.

Hal yang paling signifikan dari disiplin ini adalah berkaitan dengan waktu. Karena itulah, disiplin dalam penggunaan waktu perlu diperhatikan dengan saksama. Hal ini disebabkan karena waktu yang sudah berlalu tak mungkin dapat kembali lagi. Begitu pentingnya waktu sehingga berbagai bangsa memberikan penghargaan terhadap pentingnya waktu. Orang 
Inggris mengatakan Time is money (waktu adalah uang), sedangkan peribahasa Arab mengatakan waktu adalah pedang atau waktu adalah peluang emas, dan kita orang Indonesia mengatakan sesal dahulu pendapatan sesal kemudian tak berguna. Jadi, orang yang sukses dalam hidupnya itu adalah orang yang hidup teratur dan berdisiplin dalam memanfaatkan waktunya. Disiplin tidak akan datang dengan sendirinya, akan tetapi melalui latihan yang ketat dalam kehidupan pribadinya.

\section{Disiplin Waktu dalam Perspektif Islam}

Ada empat cara agar kita tidak menjadi orang yang lalai terhadap waktu, yaitu: (1) beriman, (2) beramal saleh, (3) saling berwasiat dalam kebenaran, (4) saling berwasiat dalam kesabaran. Inilah yang dijelaskan dalam ayat terakhir QS. al-Ashr:

"Kecuali orang-orang yang beriman dan mengerjakan amal saleh dan menasihat-menasihati supaya menaati kebenaran serta menasihatmenasihati supaya tetap dalam kesabaran"(QS. al-Ashr [103]: 3).

\section{a. Beriman}

Iman secara bahasa bermakna "membenarkan", yang berarti membenarkan segala hal yang disampaikan oleh Nabi Muhammad yang pokokpokoknya tersistematisasikan dalam rukun iman. Iman sifatnya abstrak, dimensinya batiniah atau tidak terlihat. Karenanya, yang paling tahu apakah iman seseorang itu kuat atau lemah hanyalah Allah Zat yang Maha Mengetahui masalah gaib. Walaupun iman itu abstrak, namun Allah menyebutkan sejumlah ciri orang-orang yang imannya benar sebagaimana di dalam QS. al-Anfal ayat 2-4:

"Sesungguhnya orang-orang yang beriman itu adalah mereka yang apabila disebut nama Allah gemetarlah hati mereka, dan apabila dibacakan kepada mereka ayat-ayat-Nya, bertambahlah iman mereka karenanya dan kepada Tuhanlah mereka bertawakal. Orang-orang yang mendirikan shalat dan menafkahkan sebagian dari rezeki yang Kami berikan pada mereka. Itulah orang-orang yang beriman dengan sebenar-benarnya. Mereka akan memperoleh beberapa derajat ketinggian di sisi Tuhannya serta ampunan dan nikmat yang mulia" (QS. al-Anfal [8]: 2-4). 
Iman itu bersifat fluktuatif, kadang-kadang meningkat dan kadangkadang menurun. Dalam suatu riwayat, disebutkan bahwa al-immanu yaziidu wa yanqushu (iman itu dapat bertambah dan bisa juga berkurang). Oleh sebab itu, kita wajib merawat iman agar tetap prima dan tidak terjerumus menjadi orang-orang yang merugi.

\section{b. Beramal Saleh}

Kata 'amiluu berasal dari kata 'amalun yang artinya pekerjaan yang dilakukan dengan penuh kesadaran. Sedangkan kata shalihaat berasal dari kata shaluha yang berarti bermanfaat atau sesuai. Jadi, amal saleh adalah aktivitas yang dilakukan dengan penuh kesadaran bahwa pekerjaan itu memberi manfaat untuk dirinya ataupun orang lain. Selain itu, pekerjaan tersebut sesuai dengan aturan-aturan yang telah ditentukan.

Syaikh Muhammad Abduh mendefinisikan amal saleh sebagai perbuatan yang berguna bagi diri pribadi, keluarga, kelompok, dan manusia secara keseluruhan. Jadi, karya atau kreativitas apa pun yang kita lakukan dengan penuh kesadaran demi kemaslahatan diri sendiri, keluarga ataupun masyarakat, dapat disebut amal saleh. Harus diingat, amal saleh itu harus dibarengi dengan iman, karena amal saleh tanpa dilandasi iman kepada Allah akan sia-sia,

"Dan Kami hadapi segala amal baik yang mereka kerjakan, lalu Kami jadikan amal itu bagaikan debu yang beterbangan" (QS. alFurqan [25]: 23).

\section{c. Saling Berwasiat dalam Kebenaran (Watawaa Shaubil Haq)}

Orang yang saling berwasiat dalam kebenaran berarti saling menasihati untuk berpegang teguh pada kebenaran. Kata al-haq di sini berarti kebenaran yang pasti, yaitu ajaran Islam. Karena itu, syarat agar manusia terhindar dari kerugian adalah mengetahui hakikat kebenaran Islam, mengamalkannya, dan menyampaikannya kepada orang lain. Siapa saja yang tidak mau mengajak manusia lain untuk berpegang pada kebenaran Islam setelah ia mengetahuinya, ia termasuk dalam golongan yang merugi.

Mengajak orang lain berada di jalan kebenaran bukan sekadar tugas para kiai, ulama, ustad ataupun lembaga dakwah, namun kewajiban setiap individu. Rasulullah bersabda, "Siapa yang melihat kemunkaran, maka ubahlah dengan kekuasaan. Apabila tidak mampu, maka ubahlah dengan lisan, dan kalau 
tidak mampu juga, maka ubahlah dengan hati, dan itulah iman yang paling lemah."

Kewajiban ini ditujukan kepada setiap individu Muslim, kapan dan di mana pun melihat kemunkaran, dan setiap Muslim wajib mengubahnya sesuai kadar kemampuan. Saling menasihati untuk berpegang teguh pada kebenaran harus dilakukan dengan ilmu, penuh kearifan, dan menggunakan kata-kata yang santun, sebagaimana Firman-Nya,

"Serulah manusia ke jalan Tuhanmu dengan hikmah dan nasihat yang baik, dan bantahlah mereka dengan cara yang baik. Sesungguhnya Tuhanmu Dialah yang lebih mengetahui siapa yang tersesat dari jalan-Nya dan Dialah yang lebih mengetahui orangorang yang mendapat petunjuk." (QS. al-Nahl [16]: 125).

\section{d. Saling Berwasiat dalam Kesabaran (Watawaa Shaubish Shabr)}

Kesabaran adalah suatu kekuatan jiwa yang membuat orang menjadi tabah menghadapi berbagai ujian. Sabar begitu penting untuk dimiliki orang yang beriman. Allah menyebut sabar sebanyak 103 kali dalam al-Qur'an dengan berbagai konteks. Jiwa sabar harus dimiliki karena ujian akan selalu mewarnai kehidupan manusia. Allah berfirman: "Dan sungguh Kami akan berikan ujian padamu dengan sedikit ketakutan, kelaparan, kekurangan harta, jiwa dan buah-buahan. Dan berikan kabar gembira orang-orang yang bersabar..." (QS. al-Baqarah [2]: 155).

\section{Disiplin dalan Beribadah}

Menurut bahasa, ibadah berarti tunduk atau merendahkan diri. Pengertian yang lebih luas dalam ajaran Islam, ibadah berarti tunduk dan merendahkan diri hanya kepada Allah yang disertai dengan perasaan cinta kepada-Nya. Dari pengertian tersebut dapat diketahui bahwa disiplin dalam beribadah itu mengandung dua hal: (1) berpegang teguh apa yang diajarkan Allah dan Rasul-Nya, baik berupa perintah atau larangan, maupun ajaran yang bersifat menghalalkan, menganjurkan, sunnah, makruh dan subhat; (2) sikap berpegang teguh yang berdasarkan cinta kepada Allah, bukan karena rasa takut atau terpaksa.

Maksud cinta kepada Allah adalah senantiasa taat kepada-Nya, sebagaimana Allah berfirman dalam QS. Ali Imran ayat 31: 
"Katakanlah: "Jika kamu (benar-benar) mencintai Allah, ikutilah aku, niscaya Allah mengasihi dan mengampuni dosa-dosamu". Allah Maha Pengampun lagi Maha Penyayang.” (QS. Ali 'Imran [3]: 31).

Ibadah itu dapat digolongkan menjadi dua, yaitu: (1) ibadah mahdah (murni), yaitu bentuk ibadah yang langsung berhubungan dengan Allah; (2) ibadah ghaira mahdah (selain mahdah), yang tidak langsung dipersembahkan kepada Allah melainkan melalui hubungan kemanusiaan. Dalam ibadah mahdah (disebut juga ibadah khusus), aturan-aturannya tidak boleh semaunya akan tetapi harus mengikuti aturan yang sudah ditetapkan oleh Allah dan Rasul-Nya. Orang yang mengada-ada aturan baru, misalnya shalat subuh 3 rakaat atau puasa 40 hari terus-menerus tanpa berbuka, adalah orang yang tidak disiplin dalam ibadah, karena tidak mematuhi aturan yang telah ditetapkan oleh Allah dan Rasul-Nya. Selain itu, ia termasuk orang yang berbuat bid'ah dan tergolong sebagai orang yang sesat.

Dalam ibadah ghairu mahdhah (disebut juga ibadah umum) orang dapat menentukan aturannya yang terbaik, kecuali yang jelas dilarang oleh Allah. Tentu saja suatu perbuatan dicatat sebagai ibadah kalau niatnya ikhlas semata-mata karena Allah, bukan karena riya ingin mendapatkan pujian orang lain.

\section{Disiplin dalam Bermasyarakat}

Hidup bermasyarakat adalah fitrah manusia. Dilihat dari latar belakang budaya setiap manusia memiliki latar belakang yang berbeda. Karenanya, setiap manusia memiliki watak dan tingkah laku yang berbeda. Namun demikian, dengan bermasyarakat (animal education/hayawunnatiq), mereka telah memiliki norma-norma dan nilai-nilai kemasyarakatan serta peraturan yang disepakati bersama yang harus dihormati dan dihargai serta ditaati oleh setiap anggota masyarakat tersebut.

Agama Islam mengibaratkan anggota masyarakat itu bagaikan satu bangunan yang di dalamnya terdapat beberapa komponen yang satu sama lain mempunyai fungsi yang berbeda-beda, manakala salah satu komponen rusak atau binasa. Nabi pernah menegaskan:

"Seorang Mukmin dengan Mukmin lainnya bagaikan bangunan yang sebagian dari mereka memperkuat bagian lainnya. Kemudian beliau menelusupkan jari-jari tangan sebelah lainnya." (HR. Bukhari Muslim dan Turmudzi). 


\section{Disiplin dalam Kehidupan Berbangsa dan Bernegara}

Negara adalah alat untuk memperjuangkan keinginan bersama berdasarkan kesepakatan yang dibuat oleh para anggota atau warga negara tersebut. Tanpa adanya masyarakat yang menjadi warganya, negara tidak akan terwujud. Oleh karena itu, masyarakat merupakan prasyarat untuk berdirinya suatu negara. Tujuan dibentuknya suatu negara adalah seluruh keinginan dan cita-cita yang diidamkan oleh warga masyarakat dapat diwujudkan dan dapat dilaksanakan. Rasulullah bersabda yang artinya:

"Seorang Muslim wajib mendengar dan taat, baik dalam hal yang disukainya maupun hal yang dibencinya, kecuali bila ia diperintah untuk mengerjakan maksiat. Apabila ia diperintah mengerjakan maksiat, maka tidak wajib untuk mendengar dan taat" (HR. Bukhari dan Muslim).

\section{Kenakalan Remaja dalam Islam}

Dalam melihat kenakalan remaja ini, Islam telah mengajarkan melalui Hadis Nabi dan juga ayat-ayat dalam Al-Qur'an. Dalam berkaitan dengan kontrol diri yang bisa mengeliminasi kenakalan remaja, Rasulullah pernah bersabda yang diriwayatkan dari Abu Hurairah:

"Orang perkasa bukanlah orang yang menang dalam perkelahian, tetapi orang yang perkasa adalah orang yang mengendalikan dirinya ketika marah" (HR. Bukhari dan Muslim).

Dalam riwayat yang lain, Rasulullah bersabda yang diriwayatkan dari Nu'man bin Basyir bahwa:

"Perumpamaan orang-orang mukmin dalam saling mencintai, saling mengasihi, dan saling menyayangi, seperti satu tubuh. Apabila satu organ tubuh merasa sakit, akan menjalar kepada semua organ tubuh, yaitu tidak dapat tidur dan merasa demam" (HR. Muslim).

Rasulullah juga bersabda:

"Siapa saja yang menahan marah, padahal dia mampu melampiaskannya, maka Allah akan memanggilnya pada hari kiamat di atas kepala para makhluk hingga dipilihkan baginya bidadari yang dia sukai"(HR atTirmidzi, Abu Dawud dan Ibnu Majah).

Hadis yang lain juga menyebutkan: 
"Sesungguhnya marah itu dari setan dan sesungguhnya setan itu diciptakan dari api, sementara api bisa dipadamkan oleh air. Karena itu, jika salah seorang di antara kalian sedang marah, hendaklah dia berwudhu" (HR. Abu Dawud dari Athiyah).

Hadis lain juga menyatakan:

"Apabila salah seorang di antara kalian sedang marah dalam keadaan berdiri, hendaklah dia duduk jika kemarahan itu dapat hilang. Apabila (kemarahan) itu tidak hilang, hendaklah dia berbaring." (HR. Abu Dawud dari Abu Dzar).

Dalam Surah Ali 'Imran 134, Allah berfirman yang artinya:

"(Yaitu) orang-orang yang menafkahkan (hartanya), baik pada waktu lapang maupun sempit, serta orang-orang yang menahan amarahnya dan memaafkan (kesalahan) orang. Allah menyukai orang-orang yang berbuat kebajikan" (QS Ali 'Imran [3]: 134).

Selain berkaitan dengan kontrol diri dan amarah, Islam juga mengajarkan tentang pentingnya pergaulan dan teman yang baik. Dalam hal ini, Allah berfirman:

"Dan (ingatlah) hari (ketika itu) orang yang zalim menggigit dua tangannya seraya berkata: "Aduhai kiranya (dulu) aku mengambil jalan bersama-sama Rasul." Kecelakaan besarlah bagiku; kiranya aku (dulu) tidak menjadikan si Fulan itu teman akrab(ku). Sesungguhnya dia telah menyesatkan aku dari Al-Quran ketika Al-Quran itu telah datang kepadaku. Dan adalah syaitan itu tidak mau menolong manusia" (QS. al-Furqan [25]: 27-29)

Dalam ayat yang lain, Allah berfirman:

"Dan bersabarlah kamu bersama dengan orang-orang yang menyeru Rabbnya di pagi dan di senja hari dengan mengharap keridhaan-Nya. Dan janganlah kedua matamu berpaling dari mereka karena mengharapkan perhiasan kehidupan dunia ini. Dan janganlah kamu mengikuti orang yang hatinya telah Kami lalaikan dari mengingat Kami, serta menuruti hawa nafsunya dan adalah keadaannya itu melewati batas." (QS. al-Kahfi [18]: 28).

Selain itu, Rasulullah juga menegaskan bahwa:

"Sesungguhnya perumpamaan teman yang baik (shalihah) dan teman yang jahat adalah seperti pembawa minyak wangi dan peniup api pandai besi. 
Pembawa minyak wangi mungkin akan mencipratkan minyak wanginya itu atau engkau membeli darinya atau engkau hanya akan mencium aroma harumnya itu. Sedangkan peniup api tukang besi mungkin akan membakar bajumu atau engkau akan mencium darinya bau yang tidak sedap" (HR Bukhari, dalam kitab Buyuu', Fathul Bari 4/323 dan Muslim kitab Albir 4/2026)

Syaikh Ahmad bin 'Abdurrahman bin Qudamah al-Maqdisi atau terkenal dengan nama Ibnu Qudamah al-Maqdisi memberikan nasihatnya juga dalam memilih teman:

"Ketahuilah, bahwasanya tidak dibenarkan seseorang mengambil setiap orang jadi sahabatnya, tetapi dia harus mampu memilih kriteria-kriteria orang yang dijadikannya teman, baik dari segi sifatsifatnya, perangai-perangainya atau lainnya yang bisa menimbulkan gairah berteman sesuai pula dengan manfaat yang bisa diperoleh dari persahabatan tersebut itu. Ada manusia yang berteman karena tendensi dunia, seperti karena harta, kedudukan atau sekadar senang melihat-lihat dan bisa ngobrol saja, tetapi itu bukan tujuan kita. Ada pula orang yang berteman karena kepentingan Dien (agama), dalarn hal inipun ada yang karena ingin mengambil faidah dari ilmu dan amalnya, karena kemuliaannya atau karena mengharap pertolongan dalam berbagai kepentingannya. Tapi, kesimpulan dari semua itu orang yang diharapkan jadi teman hendaklah memenuhi lima kriteria berikut: Dia cerdas (berakal), berakhlak baik, tidak fasiq, bukan ahli bid'ah dan tidak rakus dunia. Mengapa harus demikian? Karena kecerdasan adalah sebagai modal utama, tak ada kebaikan jika berteman dengan orang dungu, karena terkadang ia ingin menolongmu tapi malah mencelakakanmu. Adapun orang yang berakhlak baik, itu harus. Karena terkadang orang yang cerdaspun kalau sedang marah atau dikuasai emosi, dia akan menuruti hawa nafsunya. Maka tak baik pula berteman dengan orang cerdas tetapi tidak berakhlak. Sedangkan orang fasiq, dia tidak punya rasa takut kepada Allah. Dan barang siapa tidak takut pada Allah, maka kamu tidak akan aman dari tipu daya dan kedengkiannya. Dia juga tidak dapat dipercaya. Kalau ahli bid'ah jika kita bergaul dengannya dikhawatirkan kita akan terpengaruh dengan jeleknya kebid'ahannya itu. (Mukhtasar Minhajul Qasidin, Ibnu Qudamah hlm 99).

Dari petunjuk agamanya, seorang Muslim akan mengetahui bahwa teman itu ada dua macam. Pertama, teman yang shalih dan shalihah, dan dia laksana pembawa minyak wangi yang menyebarkan aroma harum dan 
wewangian. Kedua, teman yang jelek laksana peniup api pandai besi, orang yang di sisinya akan terkena asap, percikan api atau sesak nafas, karena bau yang tak enak.

Karena itulah, sebagai umat Islam yang baik, alangkah bagusnya membaca nasihat Bakr bin Abdullah Abu Zaid:

"Hati-hatilah dari teman yang jelek...! Karena sesungguhnya tabiat itu suka meniru, dan manusia seperti serombongan burung yang mereka diberi naluri untuk meniru dengan yang lainnya. Maka hatihatilah bergaul dengan orang yang seperti itu, karena dia akan celaka, hati- hatilah karena usaha preventif lebih mudah daripada mengobati." Maka pandai-pandailah dalam memilih teman, carilah orang yang bisa membantumu untuk mencapai apa yang engkau cari dan bisa mendekatkan diri pada Rabbmu, bisa memberikan saran dan petunjuk untuk mencapai tujuan muliamu."

Dari nasihat tersebut, umat Islam tentu saja harus berhati-hati dengan berbagai macam teman. Namun demikian, kita tetap diperintahkan untuk berbuat baik kepada siapapun, namun berbuat baik ini tentu tidak boleh melenakan kita untuk tidak terpengaruh dari berbagai hal yang tidak baik yang ditimbulkan dari setiap orang yang ada di sekeliling kita. Karena itu, berikut ini adalah berbagai kriteria yang bisa muncul dari orang-orang di sekeliling kita: 1) teman yang bisa memberikan manfaat, 2) teman yang bisa memberikan kesenangan (kelezatan), 3) teman yang bisa memberikan keutamaan

Dua jenis yang pertama itu rapuh dan mudah terputus karena terputus sebab-sebabnya. Adapun jenis ketiga, itulah yang dimaksud persahabatan sejati. Adanya interaksi timbal balik karena kokohnya keutamaan masingmasing keduanya. Namun jenis ini pula yang sulit dicari. (Hilyah Tholabul ilmi, Bakr Abdullah Abu Zaid hal. 47-48).

'Adiy bin Zayd al-'Tbadiy dalam kitabnya Diwan al-Ma'aniy (1/124) dan juga disebutkan oleh al-Zurnuji dalam kitabnya Ta'lim al-Muta'allim: "Tentang (kepribadian) seseorang janganlah engkau tanyakan dan lihatlah siapa temannya. Sesungguhnya teman dengan persahabatannya itu pasti mengikuti."

Dari berbagai ayat dan hadis serta nasihat di atas, tentu saja setiap Muslim wajib berhati-hati dalam berperilaku dan tidak boleh terpengaruh 
dengan kejelekan yang ditimbulkan dari lingkungannya. Pentingnya waspada terhadap lingkungan dan pengaruhnya ini, Rasulullah Saw. bersabda melalui Abu Hurairah r.a.:

"Tidak ada dari seorang anak (Adam) melainkan dilahirkan atas fitrah (Islam), maka kedua orangtuanyalah yang menjadikannya beragama Yahudi atau beragama Nasrani atau beragama Majusi. Bagaikan seekor binatang yang melahirkan seekor anak. Bagaimana pendapatmu, apakah didapati kekurangan? Kemudian Abu Hurairah membaca firman Allah (QS. ar-Rum [30]: 30). (Tetaplah atas) fitrah Allah yang telah menciptakan manusia menurut fitrah itu. Tidak ada perubahan pada fitrah Allah (agama Allah) (HR. Muttafaq 'Alaih).

Hadis di atas menjelaskan tentang status fitrah setiap anak, bahwa statusnya bersih, suci dan Islam baik anak seorang Muslim ataupun orang non-Muslim. Kemudian orangtuanyalah yang memelihara dan memperkuat keislamannya atau bahkan mengubah menjadi tidak Muslim, seperti Yahudi, Nasrani, dan Majusi. Hadis ini memperkuat bahwa pengaruh orang tua sangat dominan dalam membentuk kepribadian seorang dibandingkan dengan faktor-faktor pengaruh pendidikan lain. Kedua orang tua mempunyai tanggung jawab yang lebih besar dalam mendidik anaknya.

Jadi, faktor lingkungan sangat mempengaruhi bagaimana seseorang itu dibentuk, dan faktor lingkungan terkecil tentu saja adalah keluarga. Karena itulah, pendidikan di dalam keluarga haruslah bersendikan agama sehingga anak-anaknya akan melandasi kehidupannya dengan tuntunan agama.

Dalam hal ini, ada sebuah hadis dari Syuhaib, Rasulullah bersabda:

"Dahulu ada seorang raja, dia mempunyai seorang ahli sihir. Setelah ahli sihir itu tua, dia berkata kepada sanga raja: Aku telah tua, kirimkan kepadaku seorang anak remaja untuk aku ajarkan kepadanya ilmu sihir. Kemudian didatangkan kepadanya seorang anak remaja untuk diajarinya. Di jalan yang dilalui anak itu ketika pergi kepada ahli sihir itu ada seorang pendeta. Maka ia mampir kepada pendeta itu dan mendengarkan ajarannya. Ternyata ajaran pendeta itu sangat mengagumkan baginya. Setiap remaja yang datang terlambat kepada ahli sihir itu, dia dipukulnya, lalu dia mengadu kepada si pendeta. Pendeta itu berkata: Jika kamu takut kepada ahli sihir karena terlambat datang, katakanlah kepadanya aku terlambat karena dihalangi keluarga. Dan jika kamu takut kepada keluargamu, katakanlah kepadanya, aku terlambat pulang karena dihalangi ahli 
sihir. Maka berjalanlah suasana demikian dalam beberapa waktu. Pada suatu ketika, dia melewati seekor binatang besar yang menghambat manusia berlalu lintas, lalu anak remaja itu berkata: sekarang aku akan tahu, si ahli sihirkah yang lebih utama atau si pendeta? Kemudian diambillah sebuah batu, lalu dia mengucapkan: Ya Allah, jika ilmu pendeta itu lebih engkau senangi daripada ilmu tukang sihir, bunuhlah binatang itu sehingga orang-orang pun dapat lewat. Setelah peristiwa itu, remaja pergi mendatangi pendeta memberitahukan kejadian tersebut. Kata pendeta kepadanya: Wahai anakku, sekarang kamu lebih utama daripadaku. Ilmu yang kamu miliki telah sampai pada tujuan yang telah aku harapkan. Akan tetapi, kamu harus ingat bahwa kamu akan mendapat cobaan. Jika kamu telah dicoba, janganlah sampai menunjukkan bahwa akulah yang mengajarimu. Remaja itu dapat menyembuhkan orang buta sejak lahir dan orang yang terkena penyakit kusta. Bahkan ia dapat mengobati berbagai macam penyakit yang diderita manusia... (HR. Muslim).

Hadis di atas merupakan potongan dari teks hadis panjang yang menjelaskan tentang suatu kasus yang terjadi pada masa umat terdahulu. Berita hadis yang disampaikan Nabi termasuk berita gaib yang tidak diketahui sebelumnya, kecuali melalui periwayatan yang shahih seperti hadis di atas. Hadis ini menjelaskan bagaimana keberhasilan pendidikan seorang bergantung guru yang memengaruhinya. Pengaruh seorang guru dari kalangan ahli agama lebih berhasil daripada guru tukang sihir, karena kebenaran ajarannya dapat dibuktikan oleh muridnya sehingga menumbuhkan kepercayaan yang kuat terhadap gurunya.

\section{Kesimpulan}

Dari pembahasan di atas, bisa dinyatakan bahwa kedisiplinan dan kenakalan remaja itu memang ada keterkaitan yang erat. Banyak yang membuktikan hal itu melalui berbagai penelitian yang telah disebutkan dalam pembahasan di atas. Dalam hal ini, kedisiplinan itu berkorelasi terbalik dengan kenakalan remaja. Artinya, jika seorang remaja itu disiplin dan menerapkan kedisiplinan tersebut di dalam berbagai aspek kehidupannya, maka remaja tersebut akan berkurang tingkat kenakalannya yang bersifat destruktif, bahkan akan tereliminasi sama sekali. Karena itulah, faktor terpenting dalam menghentikan kenakalan remaja adalah bagaimana menerapkan kedisiplinan pada diri remaja di dalam berbagai aspek kehidupannya. 
Untuk bisa mengarah kepada hal itu, pola pendidikan adalah hal yang sangat penting, dan hal ini dimulai dari orangtua, kemudian sekolah dan lingkungan yang lebih luas. Semuanya harus bersinergi dalam membentuk kedisiplinan yang baik pada setiap anak, sehingga mereka akan terbentuk sebagai generasi yang berakhlak, berdisiplin, dan berkarakter yang baik.

Semua itu dibahas dalam psikologi Barat dan juga tentu saja dalam pola pendidikan yang ada dalam Islam. Seperti yang telah dibahas di atas, psikologi Barat dan Islam lebih menitikberatkan pada bagaimana anak mendapatkan pendidikan yang baik dengan mengajarkan akhlak yang baik dan kedisiplinan terhadap waktu, pandai dalam memilih teman, dan mampu membawa diri dalam setiap lingkungan yang dihadapi.[]

\section{Daftar Pustaka}

Alboukordi, Sajad, et al. "Predictive factors for juvenile delinquency: the role of family structure, parental monitoring and delinquent peers." International Joumal of Criminology and Sociological Theory 5.1 (2012).

Aroma, Iga Serpianing, and Dewi Retno Suminar. "Hubungan Antara Tingkat Kontrol Diri dengan Kecenderungan Perilaku Kenakalan Remaja." Jumal Psikologi Pendidikan dan Perkembangan Vol 01 No 2 (2012).

Aviyah, Evi, and Muhammad Farid. "Religiusitas, kontrol diri dan kenakalan remaja." Persona 3.02 (2014).

Hurlock, E., Perkembangan Anak, Jilid 1. Alih bahasa Tjandrasari, M. \& Muslichah. Jakarta: Erlangga, 1993.

Hurlock, E., Perkembangan Anak, Jilid 2. Alih bahasa Tjandrasari, M. \& Muslichah. Jakarta: Erlangga, 1993.

Khon, Abdul Majid. Hadis Tarbawi. Jakarta: Kencana Prenada Media Grup, 2012.

Kusumadewi, Septi, Tuti Hardjajani, and Aditya Nanda Priyatama. "Hubungan antara Dukungan Sosial Peer Group dan Kontrol Diri dengan Kepatuhan terhadap Peraturan pada Remaja Putri di Pondok Pesantren Modern Islam Assalam Sukoharjo." Jumal Imiah Psikologi Candrajiwa 1.2 (2012).

Muawanah, Lis Binti. "Kematangan Emosi, Konsep Diri dan Kenakalan Remaja." Jurnal Persona 1.1 (2012). 
Mufidah, Umri. "Efektivitas Pemberian Reward Melalui Metode Token Ekonomi untuk Meningkatkan Kedisiplinan Anak Usia Dini." BELIA: Early Childhood Education Papers 1.2 (2012).

Muhammad, Abubakar. Hadis Tarbiyah. Surabaya: Al-Ikhlas, 1995.

Nindya, P. N., and R. Margaretha. "Hubungan antara Kekerasan Emosional pada Anak terhadap Kecenderungan Kenakalan Remaja." Jumal Psikologi Klinis dan Kesehatan Mental 1.03 (2012).

Ormrod, Jeanne Ellis, Psikologi pendidikan, Jilid 1 dan 2, Jakarta: Erlangga, 2009

Pravitasari, Titis. "Pengaruh Persepsi Pola Asuh Permisif Orang Tua terhadap Perilaku Membolos." Educational Psychology Joumal 1.1 (2012).

Santrock, John. W., Psikologi Pendidikan, Jilid 1 dan 2. Jakarta: Salemba Humanika, 2014. , Perkembangan Masa Hidup, Jilid 1 dan 2. Jakarta: Erlangga, 2012. , Adolescence, Jakarta: Erlangga, 2003.

Siswanto, Fevi Zanfiana. "Hubungan Antara Kedisiplinan Melaksanakan Sholat Wajib dengan Prokrastinasi Akademik pada Mahasiswa di Fakultas Farmasi Universitas Ahmad Dahlan." Empathy: Jumal Fakultas Psikologi 2.1 (2013).

Slavin, Robert E., Psikologi Pendidikan: Teori dan Praktik, edisi kesembilan, jilid 1, Jakarta: PT Indeks, 2009.

Slavin, Robert E., Psikologi Pendidikan: Teori dan Praktik, edisi kesembilan, jilid 2, Jakarta: PT Indeks, 2011.

Woolfolk, Anita, Educational Psychology, Jilid 1 and 2. Yogyakarta: Pustaka Pelajar, 2009. 